\title{
Heavy Water Reduces GFP Expression in Prokaryotic Cell-Free Assays at the Translation Level While Stimulating Its Transcription
}

\author{
Luisa S. Hohlefelder, Tobias Stögbauer, Madeleine Opitz, \\ Thomas M. Bayerl, and Joachim O. Rädler \\ Center for Nanoscience (CeNS), Ludwig-Maximilians-Universität, Geschwister Scholl Platz 1, 80539 Munich, Germany \\ Correspondence should be addressed to Joachim O. Rädler; raedler@lmu.de
}

Received 18 October 2013; Revised 6 December 2013; Accepted 6 December 2013

Academic Editor: John B. Vincent

Copyright (C) 2013 Luisa S. Hohlefelder et al. This is an open access article distributed under the Creative Commons Attribution License, which permits unrestricted use, distribution, and reproduction in any medium, provided the original work is properly cited.

\begin{abstract}
The in vitro proliferation of prokaryotic and eukaryotic cells is remarkably hampered in the presence of heavy water $\left(\mathrm{D}_{2} \mathrm{O}\right)$. Impairment of gene expression at the transcription or translation level can be the base for this effect. However, insights into the underlying mechanisms are lacking. Here, we employ a cell-free expression system for the quantitative analysis of the effect of increasing percentages of $\mathrm{D}_{2} \mathrm{O}$ on the kinetics of in-vitro GFP expression. Experiments are designed to discriminate the rates of transcription, translation, and protein folding using pDNA and mRNA vectors, respectively. We find that $\mathrm{D}_{2} \mathrm{O}$ significantly stimulates GFP expression at the transcription level but acts as a suppressor at translation and maturation (folding) in a linear dose-dependent manner. At a $\mathrm{D}_{2} \mathrm{O}$ concentration of $60 \%$, the GFP expression rate was reduced to $40 \%$ of an undisturbed sample. We observed a similar inhibition of GFP expression by $\mathrm{D}_{2} \mathrm{O}$ in a recombinant Escherichia coli strain, although the inhibitory effect is less pronounced. These results demonstrate the suitability of cell-free systems for quantifying the impact of heavy water on gene expression and establish a platform to further assess the potential therapeutic use of heavy water as antiproliferative agent.
\end{abstract}

\section{Introduction}

Heavy water or deuterium oxide $\left(\mathrm{D}_{2} \mathrm{O}\right)$ is a stable isotope of water where deuterium $\left({ }^{2} \mathrm{H}\right)$ replaces both protium $\left({ }^{1} \mathrm{H}\right)$ atoms. Natural water comprises a low percentage of deuterium atoms (the natural abundance is about $0.01 \%$ ) which exchange between adjacent water molecules at frequencies in the $\mathrm{THz}$ range. Deuterium bonds can exhibit a higher binding energy and a shorter binding length than protium (hydrogen) bonds. Pure $\mathrm{D}_{2} \mathrm{O}$ (i.e., $99.9 \%$ deuterium enrichment) features an $11 \%$ higher density, $23 \%$ higher viscosity, and $6 \%$ higher $\mathrm{pD}$ (the equivalent of $\mathrm{pH}$ in $\mathrm{D}_{2} \mathrm{O}$ ) as compared to water. In life sciences, $\mathrm{D}_{2} \mathrm{O}$ is mainly known as an indispensable solvent and/or isotopic label in proton NMR studies of proteins [1] as well as a unique scattering contrast variation agent in neutron scattering studies of biological molecules [2]. Less well known but highly interesting and complex are its biological effects on intracellular functions [3-5]. The interest in these effects arises because of their potential for a deeper understanding of intracellular processes and the development of novel therapeutical approaches for the treatment of hyperproliferative cell diseases. In biomolecules like enzymes, receptors, DNA, and RNA, an exchange of labile (i.e., exchangeable) protons by deuterium can result in conformational changes [6] due to the fact that deuterium bonds are stronger and shorter than the comparable hydrogen bonds. For cell division and protein expression, this may have two severe consequences: at the transcription level, major enzymes like polymerases with high substrate specificity could be inhibited either directly by $\mathrm{D}$-induced conformational changes or by a $\mathrm{D}$-bond reinforced DNA double strand which may hamper its splitting up into single strands. This would lead to impairment of DNA replication and consequently of cell division and of all protein expressions. At the translational level, reduced mitotic spindle formation [7-9] most likely due to alterations of tubulin conformation by deuterium atoms replacing protons $\mathrm{H}$-bonded to the proteins may cause cell cycle arrest. Furthermore, the (partial) inhibition of protein expression 
as well as protein misfolding could trigger apoptosis or hamper cell growth and division. Although previous studies characterized the toxicity of deuterium oxide in animals [1012] by causing severe damages to specific organs such as the mouse kidney [10], deuterium oxide is still believed to have potential as an antiproliferative agent. While deuterium oxide at concentrations greater than $20 \%$ of body weight is highly toxic to animals [13], low concentrations of deuterium oxide seem to be harmless for animals and humans, and deuterated intraocular dyes are considered to be safe for clinical use [14]. Furthermore, several studies provided evidence for a significant reduction of human cancer cell lines growth in $\mathrm{D}_{2} \mathrm{O}$ culture medium [15], impairment of human tumor growth in animal models $[16,17]$, and generally a reduction of cellular proliferation at high deuterium concentrations in prokaryotic and eukaryotic cells $[16,18,19]$.

However, there is a notable scarcity of information about the underlying effects of $\mathrm{D}_{2} \mathrm{O}$ on the mechanism of gene expression in the literature. This is surprising as $\mathrm{D}_{2} \mathrm{O}$ may have the potential as an anticancer drug and/or as an adjuvant for established chemotherapeutic drugs. As the human immune system does largely not respond to $\mathrm{D}_{2} \mathrm{O}$ as a foreign molecule, side effects in therapy can be expected to be negligible, a huge advantage over all treatments available.

To obtain further insight into the effects of $\mathrm{D}_{2} \mathrm{O}$ on gene expression in cells, a method is required which can distinguish between transcription and translation in a quantitative way. A cell-free gene expression system can provide this distinction and represents a suitable model system, owing to its reduced complexity, to address this problem [20]. Here all effects revert back directly to the expression machinery due to the absence of downstream repair mechanisms which would obscure the results in cell and tissue cultures.

Here we report on the effect of $\mathrm{D}_{2} \mathrm{O}$ on protein expression using a prokaryotic cell-free system from E. coli and a GFP reporter gene. By combining this method with real-time reverse transcription PCR for mRNA quantification [21, 22], each single step of gene expression was analyzed individually. Furthermore, in order to compare the results with a more complex biological in-vitro system, GFP expression rates were examined under the influence of $\mathrm{D}_{2} \mathrm{O}$ in a recombinant $E$. coli strain. This provides some quantitative insight into the robustness of the process of gene expression in a living cell.

\section{Results}

In a first step, the overall effect of $\mathrm{D}_{2} \mathrm{O}$ on in vitro gene expression rates was studied by using a commercial prokaryotic cell-free gene expression system reconstituted of purified components from E. coli and a T7 RNA polymerase [20, 23], where $\mathrm{H}_{2} \mathrm{O}$ was replaced by $\mathrm{D}_{2} \mathrm{O} . \mathrm{D}_{2} \mathrm{O}$ concentrations in the samples ranged from $0 \%$ (control) to $60 \%$ and a fixed amount of plasmid DNA encoding GFP was added to each sample. GFP expression was quantified by fluorescence versus time over 3 hours and maximum GFP yields and expression rates were obtained as described in the methods section. As shown in Figure 1, an approximate linear reduction of both parameters was observed with increasing $\mathrm{D}_{2} \mathrm{O}$ concentration.
At a $\mathrm{D}_{2} \mathrm{O}$ concentration of $60 \%$, the GFP expression rate was reduced to $50 \%$ and the GFP yield was reduced to $40 \%$ compared to the control. A general exchange of $\mathrm{H}$-bonds by D-bonds during GFP expression can take place and affect the fluorescence properties of the GFP molecule if these exchanges are in the region of the fluorophore. As the GFP expression rate is reduced by $50 \%$ at a $\mathrm{D}_{2} \mathrm{O}$ concentration of $60 \%$, we believe that changes in the fluorescent properties of the GFP molecule are not sufficient to explain this significant decrease in GFP expression rate. Additionally, the solvent $\mathrm{D}_{2} \mathrm{O}$ might have an indirect effect on the fluorescence properties of the GFP. For a different GFP version (GFP S65T), $\mathrm{D}_{2} \mathrm{O}$ does not alter the absorbance spectra significantly [24, 25]. To verify that this observation holds true for the GFP variant used in this study, we performed a comparative analysis of the fluorescent spectra of the fluorophore diluted in $\mathrm{D}_{2} \mathrm{O}$ and $\mathrm{H}_{2} \mathrm{O}$ (see Supporting Figure 1 in Supplementary Material available online at http://dx.doi.org/10.1155/2013/592745). Our data show that the GFP fluorescence spectrum is not affected by the replacement of $\mathrm{H}_{2} \mathrm{O}$ by $\mathrm{D}_{2} \mathrm{O}$ (Supporting Figure 1), indicating that the fluorescence data shown in Figure 1 are intrinsically related to the effect of $\mathrm{D}_{2} \mathrm{O}$ on the GFP expression.

In a second step, we addressed the question at which level of gene expression $\mathrm{D}_{2} \mathrm{O}$ showed the major effect by studying transcription, translation, and protein folding separately (Figure 2).

The transcription efficiency was analyzed by running the cell-free expression kit for 4 hrs in different $\mathrm{D}_{2} \mathrm{O}$ concentrations and subsequent mRNA isolation and purification. To quantify the mRNA yields, one-tube reverse transcriptase real-time PCR using oligo-(d)T primers was applied. The threshold cycles $\left(C_{t}\right)$, being inversely related to the amount of amplicon in each sample, were calculated in order to obtain the relative amount of template cDNA, which is directly related to the relative mRNA concentration. Figures $2(a)$, and 2(b) indicate a nonlinear dose-dependent stimulating effect on the transcription by $\mathrm{D}_{2} \mathrm{O}$ with: $\Delta_{C_{t}} \mathrm{H}_{2} \mathrm{O}>\Delta_{C_{t}} \mathrm{D}_{2} \mathrm{O}$ for all $\mathrm{D}_{2} \mathrm{O}$ concentrations studied, where $\Delta_{C_{t}}=0$ represents the undisturbed sample $\left(0 \% \mathrm{D}_{2} \mathrm{O}\right)$. The maximum increase of transcription rate observed at $40 \% \mathrm{D}_{2} \mathrm{O}$ amounts to an increase of the mRNA transcription by about $250 \%$ compared to $0 \% \mathrm{D}_{2} \mathrm{O}$. At higher $\mathrm{D}_{2} \mathrm{O}$ concentration $(60 \%)$, the amount of mRNA transcribed levels off.

The effect of $\mathrm{D}_{2} \mathrm{O}$ on translation was studied by using mRNA obtained from cell-free expression in $\mathrm{H}_{2} \mathrm{O}$. This approach allowed running the transcription step of the experiment under undisturbed conditions. Then, the mRNA obtained from the undisturbed transcription was extracted, purified, and used as template in a new series of cell-free gene expression experiments at varying $\mathrm{D}_{2} \mathrm{O}$ concentrations $(0 \%, 10 \%, 20 \%, 40 \%$, and $60 \%)$. Translation rate and GFP yield were determined from time-dependent fluorescence measurements as described above. $\mathrm{D}_{2} \mathrm{O}$ significantly inhibits translation in terms of overall GFP yields (Figure 2(c)) and GFP synthesis rates (Figure 2(d)) with the maximum reduction of the rate at $60 \%$ (at a $\mathrm{D}_{2} \mathrm{O}$ concentration of $40 \%$ ) below that of the undisturbed sample. Higher concentrations of 

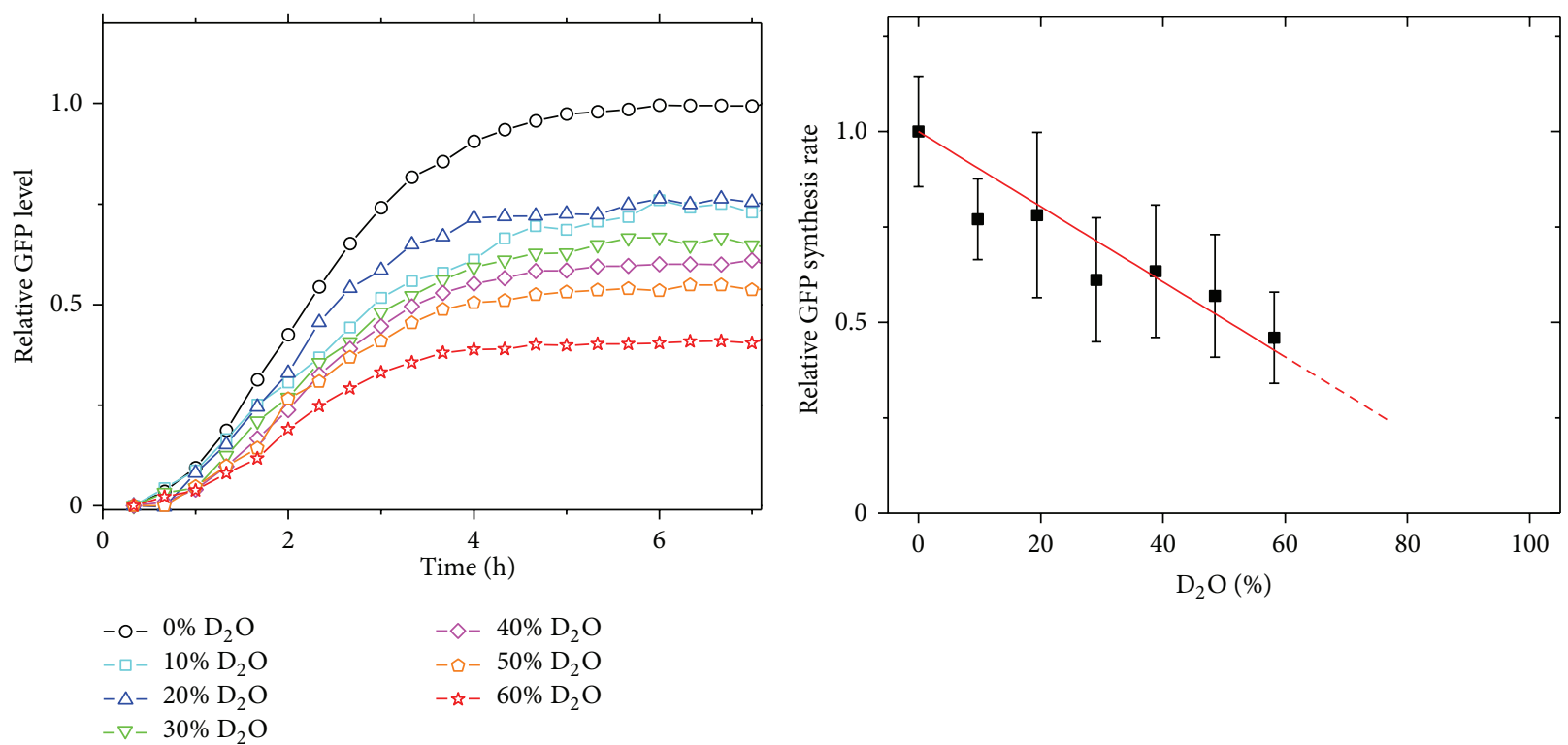

(a)

(b)

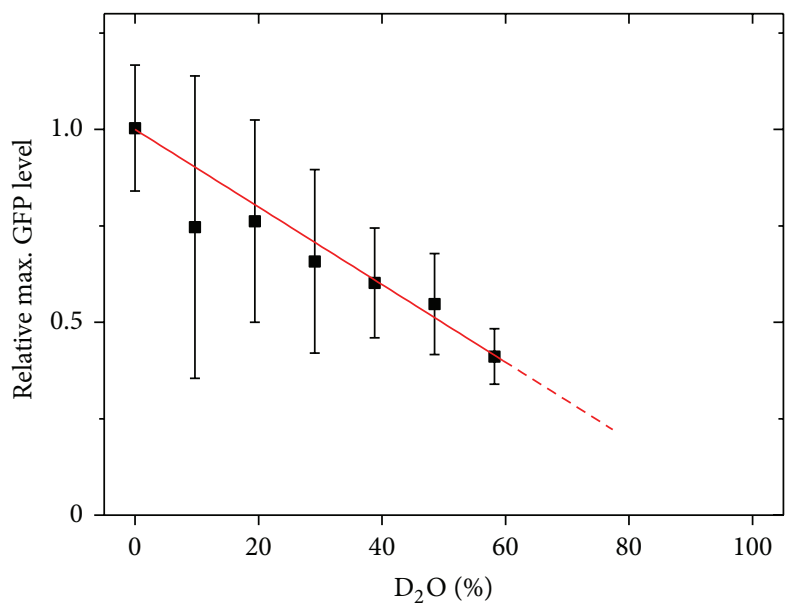

(c)

Figure 1: (a) Typical GFP expression kinetics in a cell-free system in the presence of $\mathrm{D}_{2} \mathrm{O}$ (0 to $60 \%$ ). (b) The GFP synthesis rate (mRNA transcription plus protein translation) is reduced in a deuterated environment. (c) Reduction of GFP synthesis rate results in a smaller yield of GFP when the cell-free synthesis reaction expires after about four to five hours due to degradation of ribosomes.

$\mathrm{D}_{2} \mathrm{O}$ have no further reducing effect on the in vitro translation efficiency.

In a third step, we studied the influence of $\mathrm{D}_{2} \mathrm{O}$ on GFP maturation, which is completely autocatalytic and is not dependent on the presence of molecular chaperones [26-28], by analyzing the process as a function of the GFP folding time. The antibiotic chloramphenicol, which deactivates the ribosomes and thus inhibits translation [29], was added $2 \mathrm{hrs}$ after starting the cell-free expression to ensure robust GFP expression and the GFP signal intensity was recorded. In a correctly folded protein, the GFP fluorophore is localized in the center, where it is protected from the environment. Its fluorescence is solely detectable after this final protein configuration has been adopted. Since the synthesis of new GFP is inhibited after-antibiotic addition, any further fluorescence increase is solely due to maturation of GFP translated under preantibiotic conditions. As shown in Figures 2(e) and 2(f), $\mathrm{D}_{2} \mathrm{O}$ does not inhibit GFP maturation but decreases its maturation rate by $40 \%$ (at $60 \% \mathrm{D}_{2} \mathrm{O}$ ) compared to the control $\left(\tau_{\mathrm{D}_{2} \mathrm{O}}=7,5 \mathrm{~min} ; \tau_{\mathrm{H}_{2} \mathrm{O}}=4,5 \mathrm{~min}\right)$, indicating that the maturation process itself is not affected but significantly slowed down.

To compare the results from the simplified model of a cell-free expression system with a complex, but robust biological system containing the whole set of enzymes and molecules that influence gene expression, we analyzed GFP expression by observing its time dependent fluorescence intensity in bacteria (E. coli) exposed to M63 minimal media containing different concentrations of $\mathrm{D}_{2} \mathrm{O}$ (total observation time, $5 \mathrm{~h}$ ). Figure 3(a) demonstrates an inhibitory effect of $\mathrm{D}_{2} \mathrm{O}$ on bacterial cell proliferation (growth rate) in agreement with results described elsewhere [19]. At the maximum $\mathrm{D}_{2} \mathrm{O}$ 


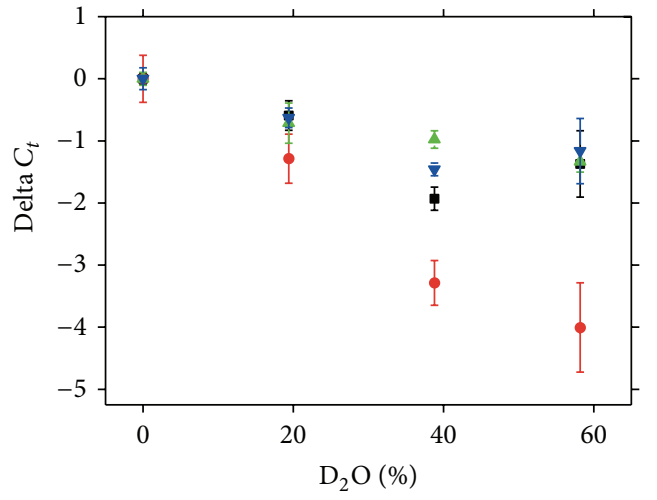

(a)

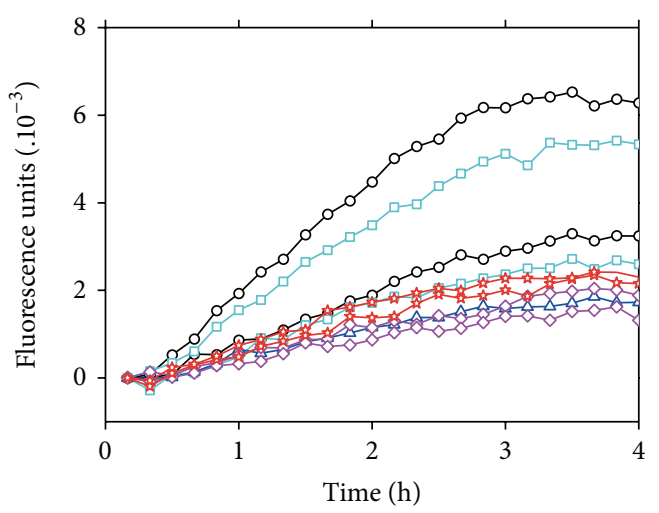

$\begin{array}{ll}\neg 0 \% \mathrm{D}_{2} \mathrm{O} & \checkmark-40 \% \mathrm{D}_{2} \mathrm{O} \\ \square-10 \% \mathrm{D}_{2} \mathrm{O} & \neg-60 \% \mathrm{D}_{2} \mathrm{O} \\ \triangle & -20 \% \mathrm{D}_{2} \mathrm{O}\end{array}$

(c)

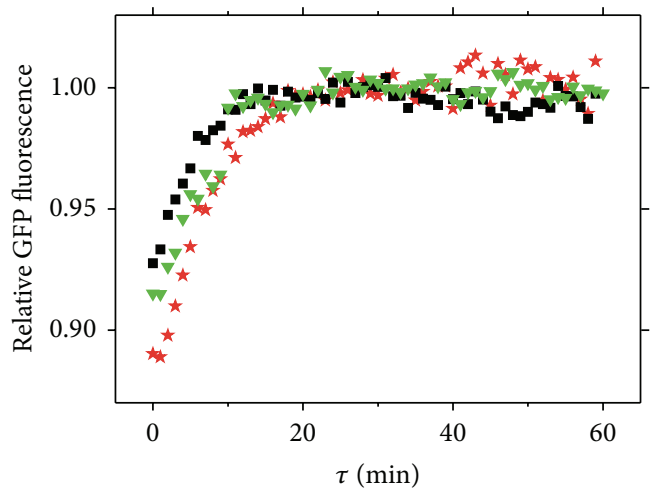

- $0 \% \mathrm{D}_{2} \mathrm{O}$

$\nabla 30 \% \mathrm{D}_{2} \mathrm{O}$

$\star 60 \% \mathrm{D}_{2} \mathrm{O}$

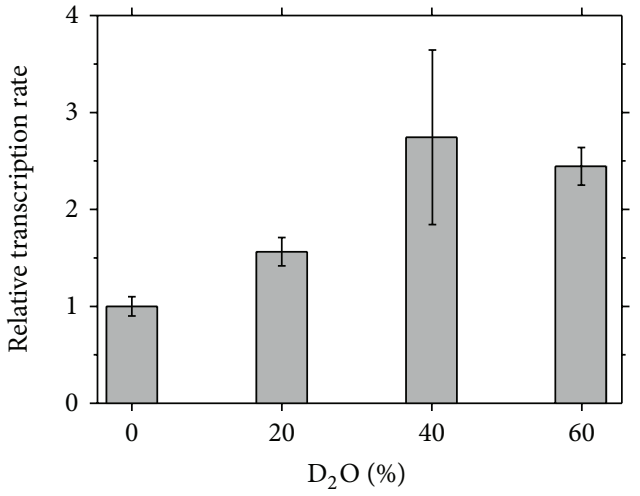

(b)

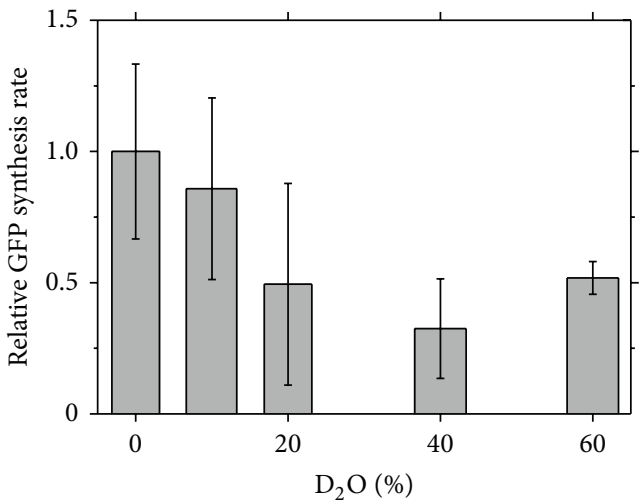

(d)

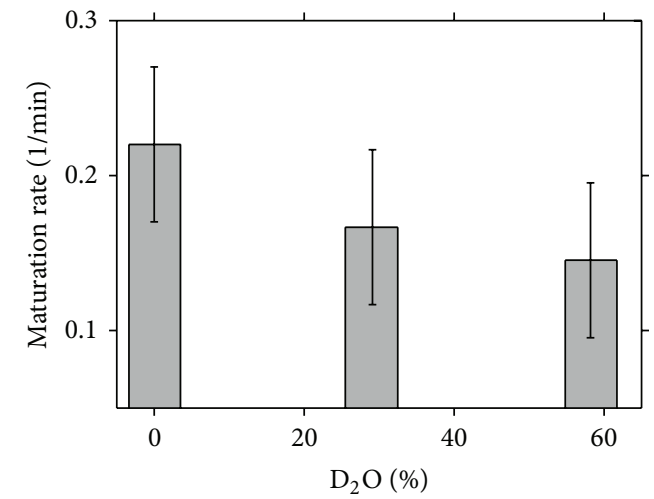

(e)

(f)

Figure 2: (a) Effect of $\mathrm{D}_{2} \mathrm{O}$ on cell-free transcription. First mRNA was transcribed in a cell-free system with $0 \%, 20 \%, 40 \%$, and $60 \% \mathrm{D}_{2} \mathrm{O}$, respectively. Then the mRNA was purified and cDNA was produced using a reverse transcriptase. The amount of cDNA in each sample was subsequently measured by real-time PCR. At $60 \% \mathrm{D}_{2} \mathrm{O}$, the mRNA yield was increased by about a factor of two to three compared to samples with $\mathrm{H}_{2} \mathrm{O}$. (b) Relative transcription rate in the presence of $\mathrm{D}_{2} \mathrm{O}$. (c) The effect of $\mathrm{D}_{2} \mathrm{O}$ on GFP translation in a cell-free system. mRNA was transcribed and purified and in a second step used as template in a cell-free system with different $\mathrm{D}_{2} \mathrm{O}$ concentrations. (d) Relative GFP synthesis rate in the presence of $\mathrm{D}_{2} \mathrm{O}$. (e) Effect of $\mathrm{D}_{2} \mathrm{O}$ on the folding time of GFP. mRNA translation in the cell-free system was stopped by adding the antibiotic chloramphenicol to the sample at the time point $t_{0}$ (ribosome deactivation). Any increase in fluorescence after $t_{0}$ is due to maturation of already translated GFP. The maturation time $\tau$ is remarkably longer in $\mathrm{D}_{2} \mathrm{O}(66 \%$ increase of $\tau$ at a concentration of $60 \%)$ than in $\mathrm{H}_{2} \mathrm{O}$. 


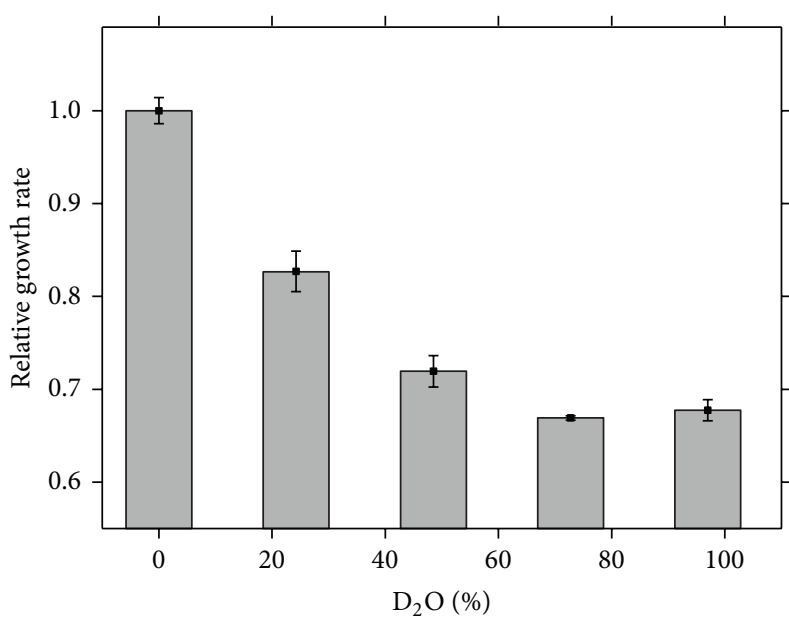

(a)

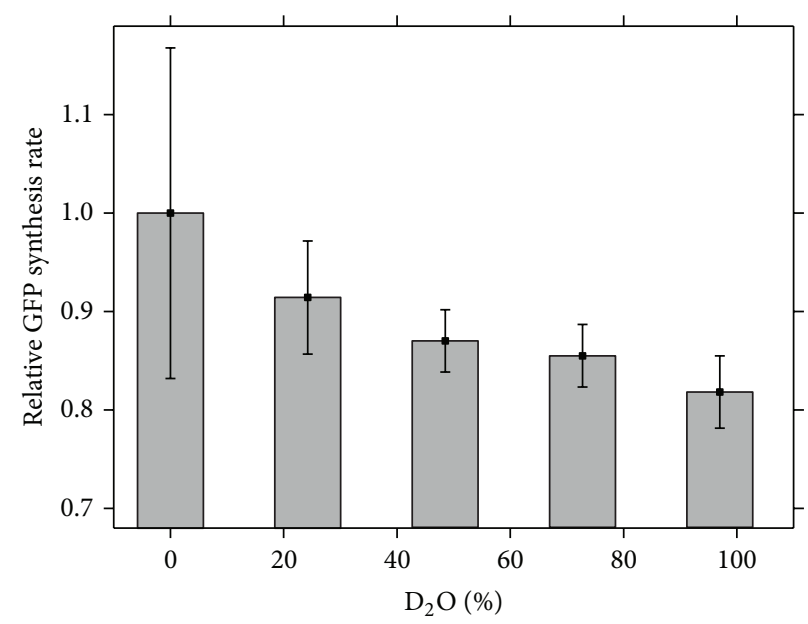

(b)

FIGURE 3: E. coli growth rate (a) and GFP expression rate as a function of $\mathrm{D}_{2} \mathrm{O}$ concentration (b).

concentration of $98 \%$, the cell growth rate was reduced to $65 \%$ of the value obtained for the control (i.e., M63 medium prepared solely with $\mathrm{H}_{2} \mathrm{O}$ ). Interestingly, the growth rate in nonlinear with the $\mathrm{D}_{2} \mathrm{O}$ concentration with the major growth inhibitory effect is observed for $\mathrm{D}_{2} \mathrm{O}$ concentrations up to $50 \%$, while at higher concentrations the effects level off. Figure $3(\mathrm{~b})$ shows that the effect of $\mathrm{D}_{2} \mathrm{O}$ on the GFP synthesis rate in $E$. coli is less pronounced but approximately linear: at the maximum concentration of $\mathrm{D}_{2} \mathrm{O}(98 \%)$, the synthesis rate is down to $83 \%$ of the control value.

\section{Discussion}

Heavy water is quite obviously a very peculiar modulator of cellular activity: it can enter the cell (or even a whole organism) quickly and undetected by any of the cellular mechanisms which would kick in for any other small molecules invading the cell. This is mostly because it passes as normal water and can use its entry (and exit) passages. Inside the cell, it readily enters all organelles, including nucleus, nucleolus, and the endoplasmic reticulum, in the same way water does, where it can cause severe damages to theses organelles [10]. In particular, it can get in contact with all hydrophilic parts of the cellular proteins and DNAs allowing the deuterons to exchange with their labile protons. Note that the speed of the $\mathrm{D}_{2} \mathrm{O}$ distribution in the cytoplasm is not limited by the self-diffusion constant of the water molecule as such but rather by the "atomic" diffusion of the deuterons which is at least one order of magnitude faster. This is because the deuterium exchange rate between individual oxygen atoms of the water is very fast (picosecond-range), giving in the time average $\mathrm{H}-\mathrm{O}-\mathrm{D}$ rather than $\mathrm{H}_{2} \mathrm{O}$ and $\mathrm{D}_{2} \mathrm{O}$. This behavior can also explain why it can pass readily through cellular and intracellular barriers, in particular membranes.

Most studies in the literature largely concentrated on the quantitative effects of $\mathrm{D}_{2} \mathrm{O}$ on intracellular processes like cell division and proliferation without providing clues about the underlying physiological and biophysical mechanisms.
However, it is essential to elucidate these processes in order to devise strategies on if and how $\mathrm{D}_{2} \mathrm{O}$ could be used in humans for the treatment of hyperproliferative organ diseases like tumors. Our results present a first step in this direction by studying the question whether the intracellular $\mathrm{D}_{2} \mathrm{O}$ effects on gene expression weight more on transcription, translation, or maturation of proteins. Here the combination of a commercially available cell-free expression system and standard real-time PCR provided a powerful tool kit to address this problem.

Our observation that $\mathrm{D}_{2} \mathrm{O}$ significantly stimulates transcription in the cell-free assay (Figures 2(a) and 2(b)) is surprising as it indicates that $\mathrm{D}_{2} \mathrm{O}$ does not solely act as a decelerator of protein activity but rather can accelerate a complex process like DNA transcription and thus increase the yield of mRNA. A rationale of this acceleration of an enzymatic reaction can only be surmised here based on the knowledge that deuterons alter hydrogen bonds: $\mathrm{D}_{2} \mathrm{O}$ may modify a rate-limiting step in the separation of the two DNA strands via the helicases by a change of the binding strength between the two strands by means of replacing $\mathrm{H}$ bonds by D-bonds $[6,30]$. Another mode of action could be improvement of enzymatic activity via stabilization of their structure [4], induction of slight changes of their folding, or by the way the enzymes bind to the DNA strand. It would be interesting to learn if a further increase of the $\mathrm{D}_{2} \mathrm{O}$ concentration beyond the upper limit of $60 \%$ as covered in the present study would push transcription efficiency even higher and where the effect may level off or reverse. However, technical limits need to be overcome prior to such a study and we will focus on this question in a separate investigation.

As we observed that overall gene expression is markedly slowed down by $\mathrm{D}_{2} \mathrm{O}$ (Figure 3 ) for the fully functional cell, we can assume that either translation and/or maturation were decelerated in the presence of $\mathrm{D}_{2} \mathrm{O}$. Indeed, our cell-free assay results indicate that both steps were similarly slowed down by $\mathrm{D}_{2} \mathrm{O}$ as schematically depicted in Figure 4 . For translation, we observed the strongest deceleration with increasing 


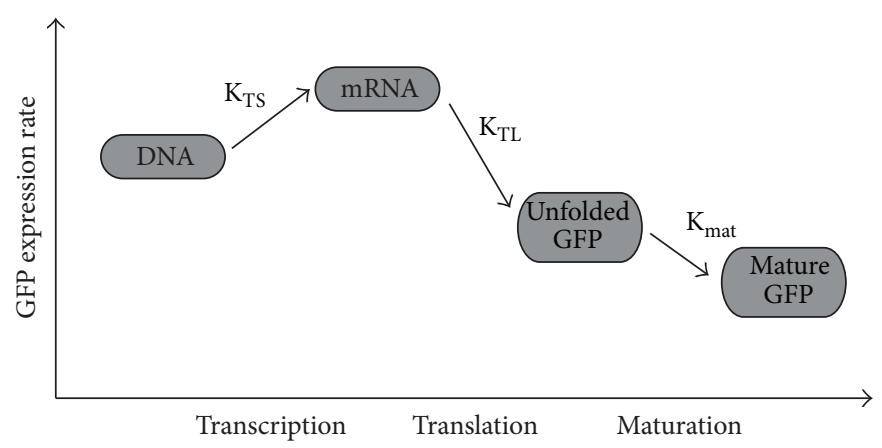

FIGURE 4: Schematics of the observed effect of $\mathrm{D}_{2} \mathrm{O}$ on transcription, translation, and GFP maturation in the cell-free protein synthesis system. Transcription efficiency was found to increase, whereas translation and maturation efficiencies were diminished. The observed overall effect of $\mathrm{D}_{2} \mathrm{O}$ on the GFP expression rate is negative (see text for details).

$\mathrm{D}_{2} \mathrm{O}$ concentration (Figures 2(c) and 2(d)). Exchange of the solvent $\mathrm{H}_{2} \mathrm{O}$ by $\mathrm{D}_{2} \mathrm{O}$ did not alter the $\mathrm{pH}$ significantly (Supporting Table 1), and we can therefore rule out effects of $\mathrm{D}_{2} \mathrm{O}$ on the $\mathrm{pH}$ as a major cause reducing the translation rate. Exchange of $\mathrm{H}$-bonds by $\mathrm{D}$-bonds during translation and/or the following maturation might affect the fluorescent properties of the GFP molecule, if such an exchange is taking place in the region of the fluorophore. But as the GFP synthesis rate drops down by more than $50 \%$, this explanation does not seem to be sufficient. A major cause could be changes in the viscosity [31-33], which is increasing with the $\mathrm{D}_{2} \mathrm{O}$ concentration: at $60 \% \mathrm{D}_{2} \mathrm{O}$, the viscosity is increased by $13.8 \%$ as compared to pure water, potentially affecting the interaction between the ribosome and the mRNA as well as amino acids. Furthermore, one may speculate that the ribosomal machinery is slowed down in a rate-limiting step by changes connected with the partial replacement of $\mathrm{H}$ atoms by deuterons in this multisubunit protein complex. The importance of water and its hydrogen-bonding networks for ribosomal function was reported by [34] which represents a major factor of the ribosomal entropic stabilization [35-37].

In the cell-free system employed for this study, maturation is essentially represented by self-contained folding of the GFP, while no chaperones are involved. Hence, the slowing down of maturation (Figures 2(e) and 2(f)) indicates that the GFP takes longer time to attain its final folding structure, possibly owing to the presence of stronger D-bonds which may require more time to break for reaching the protein's final conformation. It is well known that GFP folding comprises some dehydration steps [26-28], where a stronger D-bond may require more time to break by thermal forces. This result indicates that chaperone inhibition by $\mathrm{D}_{2} \mathrm{O}$, which was suggested previously as a major contributor to $\mathrm{D}_{2} \mathrm{O}$ induced overall slowing down or inhibition of viral gene expression [38] in cells, is rather unlikely to represent an essential factor.

It appears not surprising that we observed for the fully functional cell a reduction of gene expression being less sensitive to the $\mathrm{D}_{2} \mathrm{O}$ concentration compared to the cell-free assay. After all, the cell has a wide range of tools available to minimize the effect, in particular DNA/RNA proofing and repair mechanisms, while the T7 polymerase used in the cell-free assay is unable to perform corrections. For a mutant Chlorella algae it was recently shown [39] that gene expression becomes less sensitive to the presence of high $\mathrm{D}_{2} \mathrm{O}$ concentrations by the overexpression of certain heat shock proteins (Hsp60 and Hsp70). This suggests that misfolding and prolonged maturation of proteins may become a more important factor after repair mechanisms at the transcription and translation level kicked in.

It is interesting to note that the E. coli growth rate (Figure 3(a)) exhibits a higher sensitivity to the $\mathrm{D}_{2} \mathrm{O}$ concentration in the lower concentration range $\left(0-60 \% \mathrm{D}_{2} \mathrm{O}\right)$ than the GFP expression rate (Figure 3(b)). Here the growth rate reaches a minimum already at $50-60 \% \mathrm{D}_{2} \mathrm{O}$ concentration and does not decrease further, while GFP expression decreases linearly over the whole concentration range $(0-$ $100 \% \mathrm{D}_{2} \mathrm{O}$ ). This may indicate that $\mathrm{D}_{2} \mathrm{O}$ has a particular effect on some proteins and/or their expression involved in cell division.

\section{Conclusions}

Cell-free systems enable the analysis of the effects of different molecules on gene expression in a quantitative way in each substep. For $\mathrm{D}_{2} \mathrm{O}$, the results suggest that the stimulation of the GFP transcription is insufficient for a higher output because the downstream steps (translation and maturation) are hampered. Further studies will shed light on the molecular base of the $\mathrm{D}_{2} \mathrm{O}$ effect on each of the different substeps which may provide new clues for the use of $\mathrm{D}_{2} \mathrm{O}$ as a therapeutic drug if applied at low concentrations.

\section{Materials and Methods}

5.1. Plasmid DNA. The gfpmutl gene [40] was cloned into the pET 23b vector (Novagen, USA) between the T7 promoter and terminator sequence. pET 23b was purified and stored in deionized water at $-20^{\circ} \mathrm{C}$.

\subsection{Cell-Free System}

5.2.1. Sample Preparation. The commercial cell-free system PURExpress was ordered from New England Biolabs (Frankfurt, Germany) and used as described in the manual. Aliquots 
of PURExpress components " $\mathrm{A}$ " and " $\mathrm{B}$ " were stored at $-80^{\circ} \mathrm{C}$ and thawed on ice directly before use. Components were mixed and pET 23b DNA was added in sufficient quantity to ensure saturation of the transcription/translation apparatus [20]. Samples were diluted in $\mathrm{H}_{2} \mathrm{O}, \mathrm{D}_{2} \mathrm{O}$, or a mix of both to the desired $\mathrm{D}_{2} \mathrm{O}$ concentrations as mentioned in the text. The mixtures of $\mathrm{D}_{2} \mathrm{O}$ and $\mathrm{H}_{2} \mathrm{O}$ were prepared by diluting $\mathrm{D}_{2} \mathrm{O}$ into $\mathrm{H}_{2} \mathrm{O}$. The final $\mathrm{D}_{2} \mathrm{O} / \mathrm{H}_{2} \mathrm{O}$ mixtures were checked for their $\mathrm{pH}$ using color-fixed indicator sticks (Macherey-Nagel) sensitive for different $\mathrm{pH}$ ranges. The according $\mathrm{pH}$ values can be found in Supporting Table 1. Samples were diluted more than recommended by the manufacturer in order to achieve high $\mathrm{D}_{2} \mathrm{O}$ concentrations, leading to decreased yields of GFP. As a consequence, $\mathrm{D}_{2} \mathrm{O}$ concentrations above $60 \%$ were not studied because the dilution required would render the GFP yields below the detectability level. Typical sample volume was $12 \mu \mathrm{L}$.

5.2.2. $m R N A$ Purification. pET 23b plasmid and PURExpress were mixed and kept at $37^{\circ} \mathrm{C}$ for $3 \mathrm{hrs}$. Subsequently the "RNA cleanup" protocol of the RNeasy Mini Kit (Qiagen, USA) was applied to purify mRNA, which was used as template for cellfree "translation only" measurements.

5.2.3. cDNA Production with Reverse Transcriptase. Cell-free reactions with the desired $\mathrm{D}_{2} \mathrm{O}$ concentrations were run and mRNA was purified as described above. SuperScript II Reverse Transcriptase (Invitrogen, USA) was used to produce cDNA for downward real-time PCR measurements.

5.2.4. Data Acquisition. GFP synthesis was measured in a FLUOstar optima microplate reader (BMG LABTECH) using a 96-well plate and the top optics option. Excitation/emission filter was at $485 \mathrm{~nm} / 520 \mathrm{~nm}$. The temperature control unit was used to keep the samples at a constant $37^{\circ} \mathrm{C}$ during measurements. The 96-well plates were covered with a Breath-Easy foil (Diversified Biotech, USA) to prevent sample evaporation.

5.2.5. Data Analysis. Plate reader data were analyzed with the Origin $8.5 \mathrm{G}$ data analysis software. Maximum slopes of GFP expression versus time were determined by fitting a sigmoidal curve to the raw data and taking the derivative giving the expression rate. The GFP yield was determined from the plateau of the fluorescence versus time curve and was expressed as a percentage of the undisturbed system $\left(0 \% \mathrm{D}_{2} \mathrm{O}=100 \%\right.$ GFP yield $)$. Error bars shown in the figures represent the standard deviation at the individual measurement points calculated in Origin 8.5 G. Outliers were omitted from the statistics.

\subsection{Real-Time PCR}

5.3.1. Sample Preparation. PCR sample volume was $50 \mu \mathrm{L}$. Each sample consisted of $2 \mu \mathrm{L}$ DNA, $2 \mu \mathrm{L}$ of forward $\left(5^{\prime}-\right.$ CGC CAC CAT GGT GAG CAA GG-3') and reverse $\left(5^{\prime}-\right.$ GGT TGT CGG GCA GCA GCA CG-3') primer each, 10 mM dNTPs, $2 \mu \mathrm{L}$ Sybr Green, $2 \mathrm{U}$ Taq DNA polymerase (New
England Biolabs, Germany, ) and $0.5 \mu \mathrm{L}$ of $10 \times$ reaction buffer. The remaining $36.5 \mu \mathrm{L}$ was filled with a $\mathrm{D}_{2} \mathrm{O} / \mathrm{H}_{2} \mathrm{O}$ mix to the desired $\mathrm{D}_{2} \mathrm{O}$ concentration as indicated in the text.

5.3.2. Data Acquisition. Real-time PCR was performed on a C1000 thermal cycler equipped with the CFX96 Real-time Detection System (Bio-Rad, Germany). Reaction conditions were first denaturation at $95^{\circ} \mathrm{C}$ for $5 \mathrm{~min}$. This was followed by 30 steps of denaturation $\left(94^{\circ} \mathrm{C}, 30 \mathrm{~s}\right)$, annealing $\left(65^{\circ} \mathrm{C}, 30 \mathrm{~s}\right)$, and extension $\left(72^{\circ} \mathrm{C}, 30 \mathrm{~s}\right)$. Final extension was performed at $72^{\circ} \mathrm{C}$ for $5 \mathrm{~min}$. Analysis of gene expression using real-time PCR showed unique melting curves without primer dimers. The identity of PCR products was verified on a $1.5 \%$ agarose gel (data not shown).

5.3.3. Data Analysis. During the exponential phase of PCR, the amount of target DNA doubles with each cycle. The cycle number at which a sample crossed a manually defined threshold (called the $C_{t}$ value) is therefore indirectly proportional to the amount of template. Real-time PCR data were analyzed with the Origin $8.5 \mathrm{G}$ data analysis software. Sample curves were plotted with logarithmic $y$-axis, a threshold slightly above the background level was defined, and the $C_{t}$ values were recorded. Outliers were omitted from the statistics.

\subsection{E. coli}

5.4.1. Sample Preparation. M63 medium was prepared according to [41]. The $\mathrm{pH}$ was adjusted to 7.0 using $\mathrm{KOH}$. The medium was sterilized in an autoclave. The following additions were added to the medium: $\mathrm{MgSO}_{4} \times 7 \mathrm{H}_{2} \mathrm{O}(1 \mathrm{M})$, thiamin $(1 \mu \mathrm{g} / \mathrm{mL})$, casein hydrolysate $(0.2 \%)$, glycerol $(0.2 \%)$, ampicillin $(1000 \mathrm{ug} / \mathrm{mL})$, and arabinose $(0.2 \%)$ for maximal fluorescence induction from the inducible promoter pBAD [42]. Aliquots of M63 medium containing pure $\mathrm{H}_{2} \mathrm{O}$, $25 \%, 50 \% 75 \%$, and $98 \% \mathrm{D}_{2} \mathrm{O}$, respectively, were prepared. An overnight culture of E. coli (BZB1011-pBAD24-GFP) was grown in $\mathrm{M} 63$ with pure $\mathrm{H}_{2} \mathrm{O}$. The optical density of the culture was checked photometrically $(\mathrm{OD}=2.3) .0 .5 \mathrm{~mL}$ aliquots of M63 medium were filled into a 48-well plate. $22 \mu \mathrm{L}$ of overnight culture was added to each well, resulting in $\mathrm{OD}=0.1$ in the samples. Preparation was done in a 3 -fold redundancy for each $\mathrm{D}_{2} \mathrm{O}$ concentration for improved data accuracy.

5.4.2. Data Acquisition. Growth rate and GFP expression of E. coli as a function of $\mathrm{D}_{2} \mathrm{O}$ content of the medium were measured in a FLUOstar optima microplate reader (BMG labtech). Every $15 \mathrm{~min}$, the absorbance and GFP fluorescence of each well was detected. The plate was kept at a constant $37^{\circ} \mathrm{C}$ during measurement. $1 \mathrm{~h}$ after adding the overnight culture to the 48-well plate, GFP expression was triggered by adding $5 \mu \mathrm{L}$ of $20 \%$ arabinose solution to the wells.

5.4.3. Data Analysis. Data were analyzed using the Origin software. Individual data were averaged omitting possible outliers. For the determination of GFP expression time courses, the GFP fluorescence data were divided by the 
absorbance data in order to normalize the number of cells over time.

\section{Authors' Contribution}

Luisa S. Hohlefelder and Tobias Stögbauer contributed equally to this paper and should be considered as co-first authors.

\section{Acknowledgments}

The authors thank B. v. Bronk for his technical support. This work was supported by the Nanosystems Initiative Munich (NIM) and the Center for Nanoscience (CeNS).

\section{References}

[1] X. Guo and J. G. Kempf, "Enhanced, simplified expression of perdeuterated hemoglobin for NMR structure and dynamics," Protein Expression and Purification, vol. 72, no. 1, pp. 8-18, 2010.

[2] W. Knoll, G. Schmidt, K. Ibel, and E. Sackmann, "Smallangle neutron scattering study of lateral phase separation in dimyristoylphosphatidylcholine-cholesterol mixed membranes," Biochemistry, vol. 24, no. 19, pp. 5240-5246, 1985.

[3] A. Sen, V. Balamurugan, K. K. Rajak, S. Chakravarti, V. Bhanuprakash, and R. K. Singh, "Role of heavy water in biological sciences with an emphasis on thermostabilization of vaccines," Expert Review of Vaccines, vol. 8, no. 11, pp. 1587-1602, 2009.

[4] P. Cioni and G. B. Strambini, "Effect of heavy water on protein flexibility," Biophysical Journal, vol. 82, no. 6, pp. 3246-3253, 2002.

[5] R. Darad and A. S. Aiyar, "Effects of heavy water on mitochondrial respiration and oxidative phosphorylation," Journal of Biosciences, vol. 4, no. 2, pp. 159-166, 1982.

[6] J. Basu, N. Padhy, and A. Mookerjee, "An insight into the structure of DNA through melting studies," Indian Journal of Biochemistry and Biophysics, vol. 27, no. 4, pp. 202-208, 1990.

[7] P. R. Gross and W. Spindel, "Mitotic arrest by deuterium oxide," Science, vol. 131, no. 3392, pp. 37-39, 1960.

[8] P. J. Leonard and J. M. Mullins, " $\mathrm{D}_{2} \mathrm{O}$ induced alterations of mitosis in PtK1 cells," Experimental Cell Research, vol. 172, no. 1, pp. 204-211, 1987.

[9] J. Lamprecht, D. Schroeter, and N. Paweletz, "Derangement of microtubule arrays in interphase and mitotic PtK2 cells treated with deuterium oxide (heavy water)," Journal of Cell Science, vol. 98, no. 4, pp. 463-473, 1991.

[10] P. Bachner, D. G. McKay, and D. Rittenberg, "The pathologic anatomy of deuterium intoxication," Proceedings of the National Academy of Sciences of the United States of America, vol. 51, pp. 464-471, 1964.

[11] A. P. Amarose and D. M. Czajka, "Cytopathic effects of deuterium oxide on the male gonads of the mouse and dog," Experimental Cell Research, vol. 26, no. 1, pp. 43-61, 1962.

[12] O. Dybung, G. Guldberg, and K. Hansen, "PathologischAnatomische Veränderungen Bei Subkutaner Deuteriumoxidvergiftung Von Mäusen," Klinische Wochenschrift, vol. 17, p. 1585, 1938.
[13] D. J. Kushner, A. Baker, and T. G. Dunstall, "Pharmacological uses and perspectives of heavy water and deuterated compounds," Canadian Journal of Physiology and Pharmacology, vol. 77, no. 2, pp. 79-88, 1999.

[14] K. Januschowski, S. Mueller, M. S. Spitzer et al., "Evaluating retinal toxicity of a new heavy intraocular dye, using a model of perfused and isolated retinal cultures of bovine and human origin," Graefe's Archive for Clinical and Experimental Ophthalmology, pp. 1-10, 2012.

[15] J. Hartmann, Y. Bader, Z. Horvath et al., "Effects of heavy water $\left(\mathrm{D}_{2} \mathrm{O}\right)$ on human pancreatic tumor cells," Anticancer Research, vol. 25, no. 5, pp. 3407-3411, 2005.

[16] H. J. Altermatt, J.-O. Gebbers, and J. A. Laissue, "Heavy water delays growth of human carcinoma in nude mice," Cancer, vol. 62, no. 3, pp. 462-466, 1988.

[17] H. J. Altermatt, J.-O. Gebbers, and J. A. Laissue, "Heavy water enhances the antineoplastic effect of 5-fluoro-uracil and bleomycin in nude mice bearing human carcinoma," International Journal of Cancer, vol. 45, no. 3, pp. 475-480, 1990.

[18] H. Takeda, Y. Nio, H. Omori et al., "Mechanisms of cytotoxic effects of heavy water (deuterium oxide: $\mathrm{D}_{2} \mathrm{O}$ ) on cancer cells," Anti-Cancer Drugs, vol. 9, no. 8, pp. 715-725, 1998.

[19] K. Hirai, M. Tomida, Y. Kikuchi, O. Ueda, H. Ando, and N. Asanuma, "Effects of deuterium oxide on Streptococcus mutans and Pseudomonas aeruginosa," The Bulletin of Tokyo Dental College, vol. 51, no. 4, pp. 175-183, 2010.

[20] T. Stögbauer, L. Windhager, R. Zimmer, and J. O. Rädler, "Experiment and mathematical modeling of gene expression dynamics in a cell-free system," Integrative Biology, vol. 4, no. 5, pp. 494-501, 2012.

[21] S. A. Bustin, "Absolute quantification of mrna using real-time reverse transcription polymerase chain reaction assays," Journal of Molecular Endocrinology, vol. 25, no. 2, pp. 169-193, 2000.

[22] D. G. Ginzinger, "Gene quantification using real-time quantitative PCR: an emerging technology hits the mainstream," Experimental Hematology, vol. 30, no. 6, pp. 503-512, 2002.

[23] Y. Shimizu, T. Kanamori, and T. Ueda, "Protein synthesis by pure translation systems," Methods, vol. 36, no. 3, pp. 299-304, 2005.

[24] M. Kneen, J. Farinas, Y. Li, and A. S. Verkman, "Green fluorescent protein as a noninvasive intracellular $\mathrm{pH}$ indicator," Biophysical Journal, vol. 74, no. 3, pp. 1591-1599, 1998.

[25] D. Stoner-Ma, A. A. Jaye, K. L. Ronayne, J. Nappa, S. R. Meech, and P. J. Tonge, "An alternate proton acceptor for excited-state proton transfer in green fluorescent protein: rewiring GFP," Journal of the American Chemical Society, vol. 130, no. 4, pp. 1227-1235, 2008.

[26] S. Inouye, "Evidence for redox forms of the Aequorea green fluorescent protein," FEBS Letters, vol. 351, no. 2, pp. 211-214, 1994.

[27] R. Heim, D. C. Prasher, and R. Y. Tsien, "Wavelength mutations and posttranslational autoxidation of green fluorescent protein," Proceedings of the National Academy of Sciences of the United States of America, vol. 91, no. 26, pp. 12501-12504, 1994.

[28] R. Heim, A. B. Cubitt, and R. Y. Tsien, "Improved green fluorescence," Nature, vol. 373, no. 6516, pp. 663-664, 1995.

[29] H. Lüllmann, K. Mohr, and L. Hein, Arzneimittelwirkungen Verstehen und Medikamente Gezielt Einsetzen, Pharmakologie und Toxikologie, Georg Thieme, Stuttgart, Germany, 2006.

[30] V. Izzo, S. L. Fornili, and L. Cordone, "Thermal denaturation of $\mathrm{B}$. subtilis DNA in $\mathrm{H}_{2} \mathrm{O}$ and $\mathrm{D}_{2} \mathrm{O}$ observed by electron 
microscopy," Nucleic Acids Research, vol. 2, no. 10, pp. 1805-1810, 1975.

[31] D. L. Timrot and K. F. Shuiskaya, "An experimental investigation of the viscosity of heavy water," The Soviet Journal of Atomic Energy, vol. 7, no. 5, pp. 925-928, 1961.

[32] D. R. Lide, CRC Handbook of Chemistry and Physics, CRC Press, Boca Raton, Fla, USA, 80th edition, 1999.

[33] R. C. Weast, CRC Handbook of Chemistry and Physics, CRC Press, Cleveland, Ohio, USA, 57th edition, 1976.

[34] G. Wallin and J. Åqvist, "The transition state for peptide bond formation reveals the ribosome as a water trap," Proceedings of the National Academy of Sciences of the United States of America, vol. 107, no. 5, pp. 1888-1893, 2010.

[35] S. Trobro and J. Åqvist, "Mechanism of peptide bond synthesis on the ribosome," Proceedings of the National Academy of Sciences of the United States of America, vol. 102, no. 35, pp. 12395-12400, 2005.

[36] S. Trobro and J. Åqvist, "Analysis of predictions for the catalytic mechanism of ribosomal peptidyl transfer," Biochemistry, vol. 45, no. 23, pp. 7049-7056, 2006.

[37] S. Trobro and J. Åqvist, "Role of ribosomal protein L27 in peptidyl transfer," Biochemistry, vol. 47, no. 17, pp. 4898-4906, 2008.

[38] U. Schubert, "Agents for the inhibition of virus replication through regulation of protein folding," United States Patent Application Publication, US 2007/0141074A1, 2007.

[39] K. Unno, N. Hagima, T. Kishido, S. Okada, and N. Oku, "Deuterium-resistant algal cell line for D labeling of heterotrophs expresses enhanced level of $\mathrm{Hsp} 60$ in $\mathrm{D}_{2} \mathrm{O}$ medium," Applied and Environmental Microbiology, vol. 71, no. 5, pp. 2256-2259, 2005.

[40] B. P. Cormack, R. H. Valdivia, and S. Falkow, "FACS-optimized mutants of the green fluorescent protein (GFP)," Gene, vol. 173, no. 1, pp. 33-38, 1996.

[41] A. B. Pardee, F. Jacob, and J. Monod, "The genetic control and cytoplasmic expression of "inducibility" in the synthesis of Bgalactosidase by E. coli," Journal of Molecular Biology, vol. 1, pp. 166-178, 1959.

[42] J. A. Megerle, G. Fritz, U. Gerland, K. Jung, and J. O. Rädler, "Timing and dynamics of single cell gene expression in the arabinose utilization system," Biophysical Journal, vol. 95, no. 4, pp. 2103-2115, 2008. 

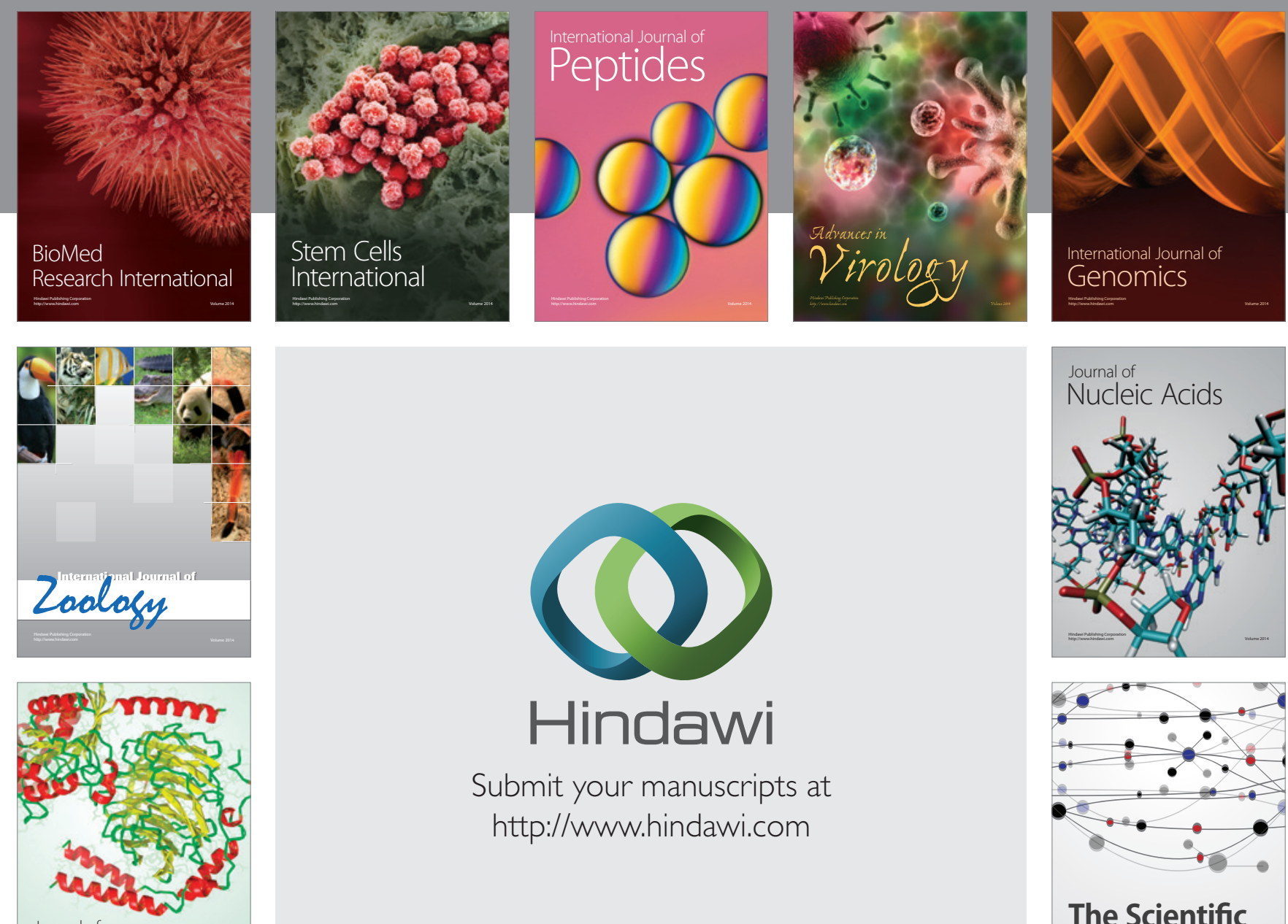

Submit your manuscripts at

http://www.hindawi.com

Journal of
Signal Transduction
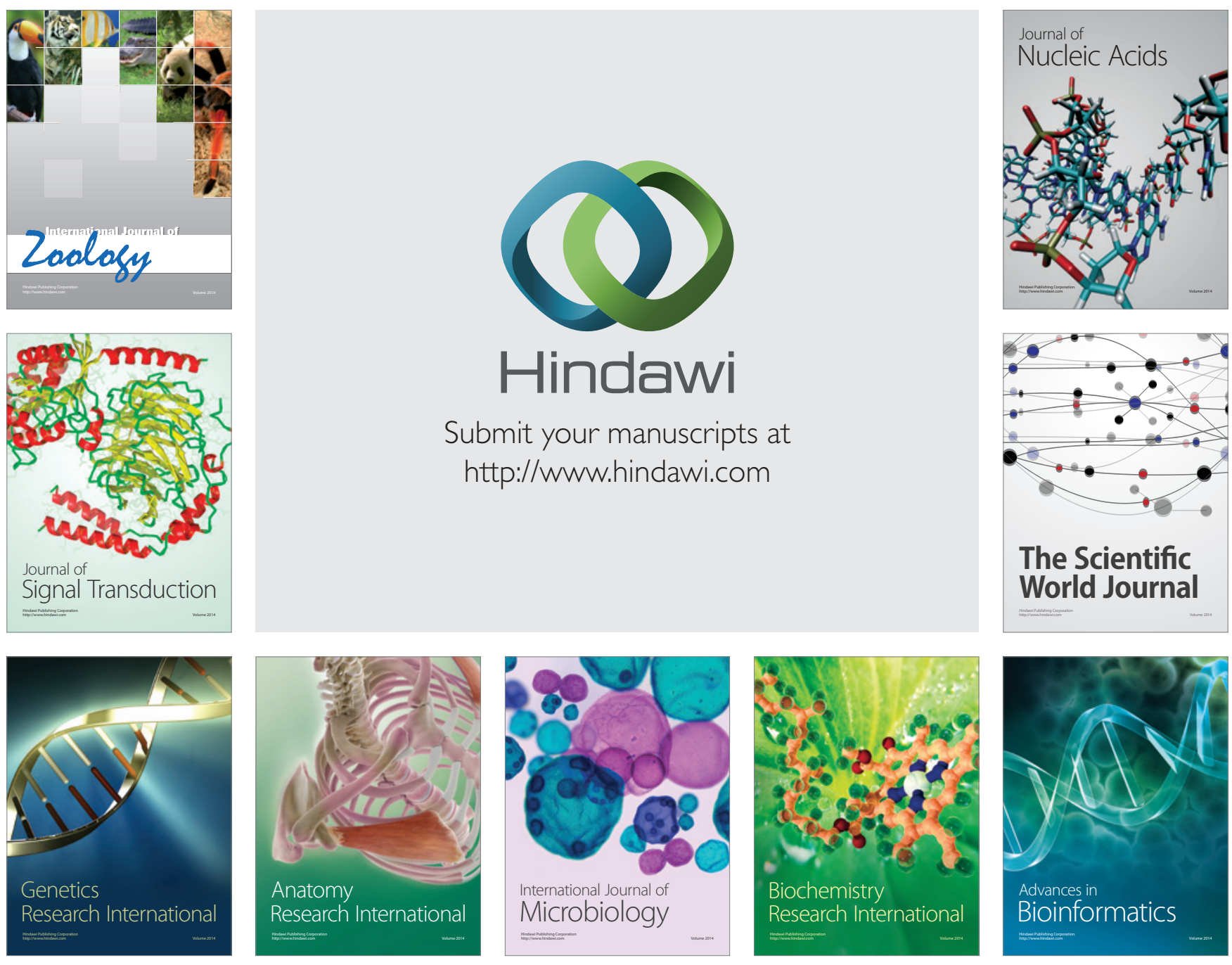

The Scientific World Journal
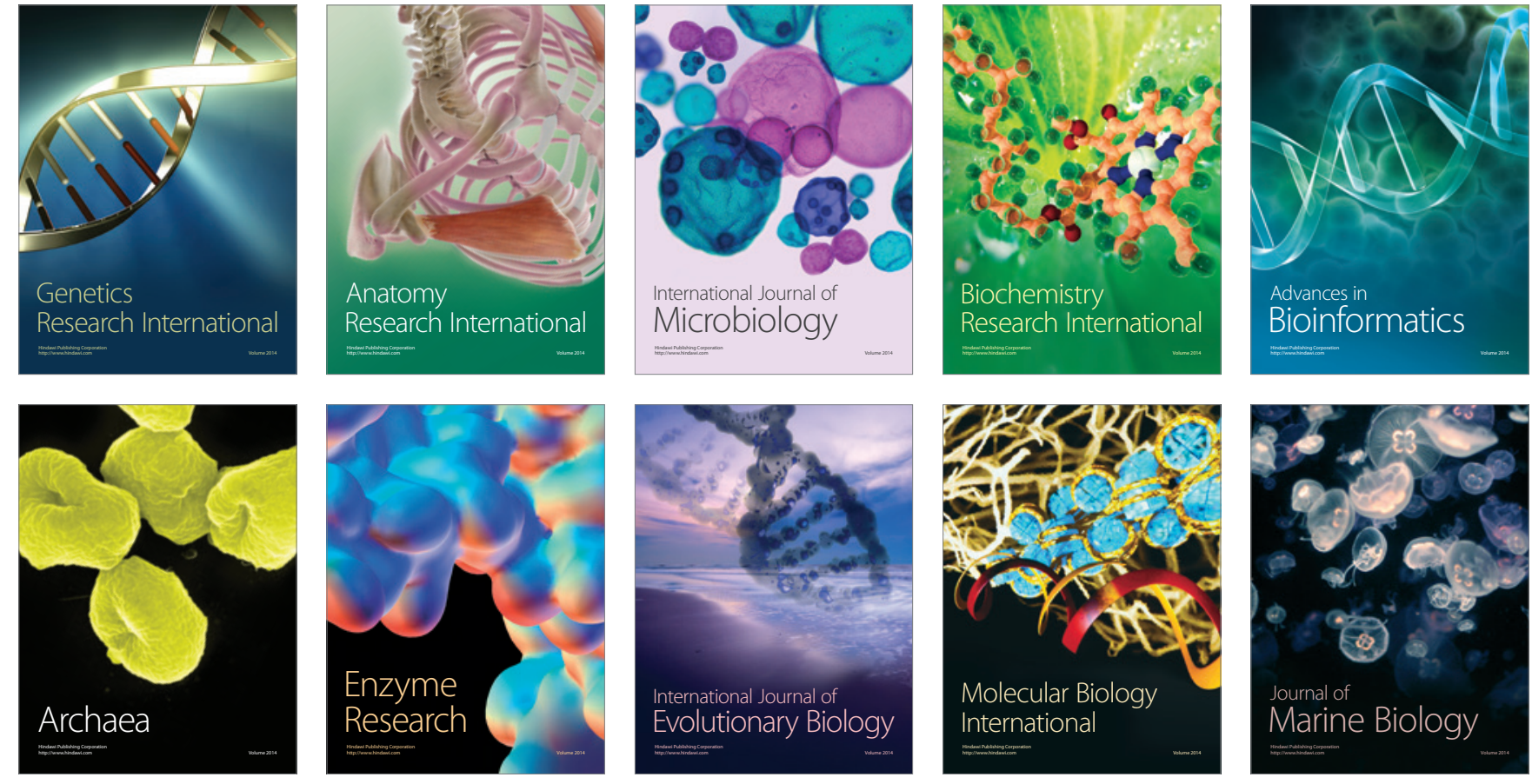